\title{
Are unborn children rights-holders under the United Nations Convention on the Rights of the Child?
}

\section{Fiona Broughton}

Department \& Faculty of Law, UCC

\section{Introduction}

In September 1992, Ireland ratified the United Nations Convention on the Rights of the Child (CRC), committing itself to the promotion, protection and fulfilment of the rights of all children on a non-discriminatory basis as outlined in the Convention. But just who is a child under the wording of the CRC? Article 1 of the CRC defines the child as "every human being below the age of eighteen years, unless under the law applicable to that child majority is attained earlier". So the CRC is clear on a maximum age limit for one to qualify as a 'child' and thus gain rights under the CRC. It makes no mention, however, of a minimum age limit for a human being to qualify as a 'child' under the Convention. Does a child gain rights under the Convention from the moment of his existence, i.e., immediately following conception, or from the moment of birth, or at some point in between? Ostensibly, the Convention is silent on the matter.

This issue of whether or not the CRC applies to pre-natal children is not one that was simply over-looked during the drafting process. Quite the converse - it was an extremely contentious issue. There were fears that states would not ratify the Convention if it explicitly afforded rights to unborn children because of the effects it might have on those states' abortion laws. On the other hand, stipulating that the CRC would only protect children 'from the moment of birth,' would make a clear statement allowing for abortion practices under a Convention whose purpose was to protect and vindicate the rights of all children on a non-discriminatory basis.

It seems that it was in an effort to facilitate ratification by as many states as possible, that the Working Group (which was responsible for drafting the text of the CRC) attempted to leave the matter of whether or not the CRC applies to the child before birth purposefully ambiguous. That way, states could decide for themselves from what point of human development a child would be protected in their jurisdiction and therefore would ratify the Convention, regardless of what their abortion laws stated. This begs the question of what possible value international human rights laws are to a child, if the state in which that child lives can decide for itself which children are entitled to those rights. 
Many of the rights enumerated in the CRC are pertinent to pre-natal children. The rights which are most overtly linked to children before birth are the rights to life, survival and development and the right to pre-natal health care. Also relevant to these children are rights to non-discrimination, the right to freedom from violence, the right to be protected from harmful acts and substances and the right to an adequate standard of living, to name but a few. Are children in the womb entitled to such rights under the CRC?

To answer this question, it must be established whether or not pre-natal children come within the scope of Article 1 of the CRC (i.e,. the definition of a child). This requires an honest and accurate interpretation of Article 1. There are vastly differing academic opinions on this matter. Philip Alston (a prominent U.S. human rights practitioner), for example, argues that the pre-natal child is not and was never intended to be included in the definition of a child in the CRC. Bruce Abramson (a human rights attorney specialising in the CRC) on the other hand, contends that the definition of a child in the CRC is and was indeed intended to be broad enough to encompass the child before birth.

The Vienna Convention on the Law of Treaties, 1969 (Vienna Convention) offers rules to aid interpretation of international treaties. Article 31.1 of the Vienna Convention states that a treaty should be interpreted $(a)$ in good faith; $(b)$ in accordance with the ordinary meaning of the terms of the treaty; $(c)$ in light of the treaty's context; and $(d)$ in light of the treaty's object and purpose. In addition, it is stated that the context in which the treaty is to be interpreted shall include its preamble (a statement of the motivation and context of the treaty). These criteria must be followed to discern whether or not the pre-natal child is included in the definition of a child under the CRC.

\section{a) The 'good faith' requirement}

Recall that Article 1 of the CRC states that "a child is every human being below the age of eighteen years unless, under the law applicable to that child, majority is attained earlier" (emphasis mine). If this statement is to be interpreted 'in good faith,' as is required by the Vienna Convention, the term which must be examined - the operative term - is in fact 'human being' rather than 'child'. The term 'child' is to be construed throughout each provision of the Convention as every human being below the age of 18 (unless in that state, the age of majority is attained earlier). Alston, in his argument that the definition of a child under the CRC does not extend to pre-natal children, focuses on terms such as 'child,' 'foetus' and 'embryo'. He avoids the term 'human being'. Abramson, on the other hand, does deal with the operative term of the Convention and uses a diagram of a set, to show that children before birth are as a matter of fact included in the term 'human being' and thereby included in the CRC.

Abramson illustrates this by way of two concentric circles (see below). The outer circle A consists of all human beings within the jurisdiction of the state while the inner circle $B$ consists of all of those human beings who are under the age of 18 or the age of majority, 


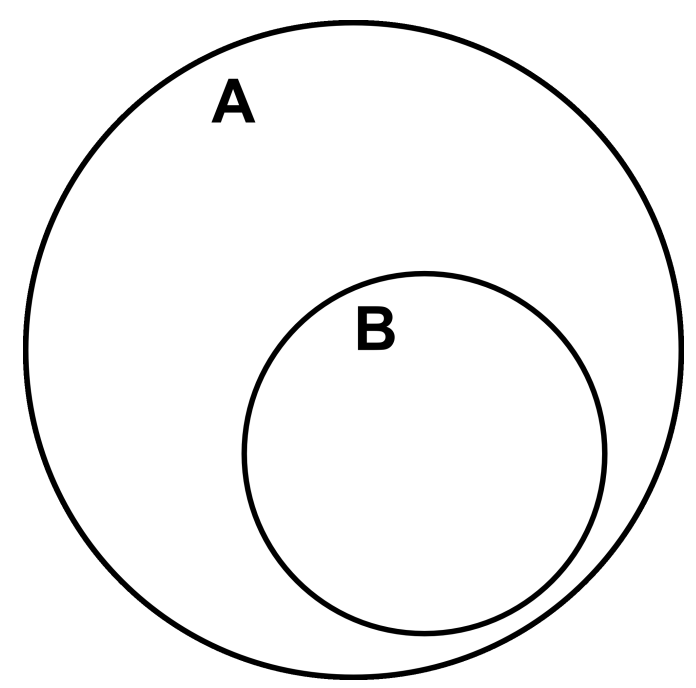

Figure 1: Outer Circle A: All human beings within jurisdiction of state; Inner Circle B: All of those human being under age of 18

whichever occurs first. Every individual within the inner circle (set B) is a child (whether pre or post-natal) and therefore a rights holder under the Convention.

The fact that Alston focuses on the term 'child' instead of 'human being' makes his argument an easier one - it is much simpler to argue that the pre-natal human being is not a 'child' than it is to argue that the pre-natal human being is not a 'human being'. However, as the Vienna Convention instructs that interpretation of Article 1 is to be conducted 'in good faith,' then the operative term of the Convention 'human being' must be discussed and not avoided.

\section{b) The 'ordinary meaning' rule}

The term 'human being' is expansive and perhaps the most all-inclusive term that could have possibly been chosen by the drafters. According to the Oxford English Dictionary, a human being is "a member of the human race". Other dictionary definitions are more specific, for example "any individual of the genus Homo, esp[ecially] a member of the species Homo sapiens" (Random House Dictionary of the English Language). Abramson rightly comments that to be a member of a species "does not call for any age or developmental test". We acquire human rights simply by virtue of being part of the human species. Therefore, it seems that the ordinary meaning of the term 'human being,' chosen by the drafters of the Convention, is inclusive enough to apply to a human being who is under 18 (or the age of majority) during the pre-natal stage of existence as well as the post-natal stage.

This assertion is lent weight by the fact that states themselves, who are party to the CRC, have interpreted the term 'human being' to refer to the developing child during the prenatal stages of existence as well as the post-natal stages. For example, a report by Argentina states that Article 1 "must be interpreted to the effect that a child means every 
human being from the moment of conception up to the age of 18". A report by Brazil refers to the special "vulnerability of the human being from conception up to approximately six years". Indeed, Abramson records that 128 out of the first 176 states to file reports with the Committee on the Rights of the Child either expressed or inferred that children before birth are 'human beings' and therefore rights holders under the Convention. It appears that the ordinary meaning of the term 'human being' does include the child in pre-natal stages of development.

\section{c) To be interpreted 'in their context'}

The Vienna Convention requires that the term 'human being' in Article 1 is interpreted in the context of the CRC as a whole. Therefore, if Article 1 is to be interpreted in accordance with the Vienna Convention, it must be read in light of other Convention provisions including, for example, the right to pre-natal care under Article 24. Article 24 recognises the right of the child to "the highest attainable standard of health" and as part of this right, recognises the right to "appropriate pre-natal care for mothers".

Health care before birth is recognised here as a child's right, notwithstanding the fact that such a child is not yet born. Although the recipient of the care is the mother, the rights holder is the child. Abramson explains that "[a]s a post-natal child's right to clean water must be directed to the water supply, a pre-natal child's right to health care must be directed to his pre-eminent environment - his mother". As this right is specific to pre-natal care, it must follow that the child is not yet born. If the rest of the Convention is to be interpreted in the context of this provision, each provision of the CRC will apply to the pre-natal child just as it does to the post-natal child.

\section{d) The 'object and purpose' rule}

The Vienna Convention states that treaty provisions should be interpreted in the light of that Treaty's 'object and purpose'. It is well established that the fundamental aim of the CRC is to develop and encourage the promotion of children's rights. It must follow from this that a retreat on existing standards of protection afforded to the rights of children would go against the CRC's object and purpose. As human rights treaties prior to the CRC already explicitly or implicitly recognise the pre-natal child as a rights holder, (for example the American Convention on Human Rights, the International Covenant on Civil and Political Rights and the International Covenant on Economic, Social and Cultural Rights), to suggest that the CRC does not protect the rights of the pre-natal child would in fact be reneging on existing standards of protection afforded to that child under existing human rights treaties and therefore would go against the object and purpose of the Convention.

\section{e) The Preamble}

The Preamble to the CRC states that "the child, by reason of his physical and mental immaturity, needs special safeguards and care, including appropriate legal protection, before 
as well as after birth" (emphasis mine). This clearly states that a child is to be considered a 'child' before birth and that a pre-natal child is entitled to legal protection.

The Vienna Convention specifies that "meaning [is] to be given to the terms of the treaty in their context... [which includes]... its preamble ...". Therefore, the definition of a child in Article 1 must be interpreted in the light of the statement in the preamble recognising explicit protection for the child before birth.

The relevant paragraph in the Preamble states that 'appropriate' legal protection must be given to children 'before as well as after birth'. What then exactly is 'appropriate' legal protection for the human rights of children? Alston asserts that what constitutes 'appropriate' protection for the human rights of pre and post-natal children is a question for each state to decide for itself. This assertion flies in the face of the underlying function and values of an international human rights instrument. Rita Joseph in Human Rights and the Unborn Child, seems to be more in tune with the very nature of human rights when, in a compelling argument, she concludes that 'appropriate' legal protection for human rights is non-discriminatory, without arbitrary interference, universal, objective and non-selective; it is protection that meets the requirements of morality, public order and the general welfare, and protection which is in line with the purposes and principles of the United Nations. Thus, it is suggested that inclusion of pre-natal children in the definition of a child under the CRC ensures that 'appropriate' legal protection is afforded to all children, without discrimination of any kind, irrespective of the child's birth or other status and irrespective of or his or her parent's political or other opinion, as is indeed required by the CRC itself.

\section{Conclusion}

At the nub of this research lies a very basic question - who is the subject of human rights? This is a vital question and not one which should be left up to each state to decide the answer for itself through arbitrary court judgments, piecemeal legislation, or as Angela Shanahan has put it "accidents of precedent". It is a question which needs to be (and is) answered explicitly in international human rights instruments themselves such as the CRC. The answer can indeed be found in an honest and accurate interpretation of the CRC, which stipulates that all children should be afforded rights on a non-discriminatory basis. The child before birth too, has a recognised place in the framework of international human rights law, and whether such a human being is termed 'embryo,' 'foetus,' or 'unborn child,' the individual in question is the very same - an immature human being at the most vulnerable and fragile stages of human development.

Fiona Broughton is a student in the Department \& Faculty of Law under the supervision of Dr. Ursula Kilkelly. The author would like to acknowledge funding from the Department \& Faculty of Law, University College Cork. 